\title{
SISITEM INFORMASI MANAJEMEN \\ MAHASISWA ADMINISTRASI PENDIDIKAN \\ SISTEM INFORMASI MANAJEMEN DI PENDIDIKAN
}

\author{
Milsa Putri Ayu \\ 17002135 \\ Program Studi Administrasi Pendidikan \\ Jurusan Administrasi Pendidikan \\ Fakultas Ilmu Pendidikan \\ Universitas Negeri Padang \\ E-mail:milsaputriayu99@gmail.com \\ ABSTRAK
}

Sistem informasi manajemen sangat bergantung dari komponen-komponen dalam menghasilkan sisitem informasi yang sesuai dengan kebutuhannya. Kesenjangan yang terjadi dalam pelaksanaan komponen tersebut akan menghasilkan informasi yang kurang akurat, kurang detail, kurang tepat waktunya, dan kurang relevan akan mengakibatkan kesalahan dalam pengambilan keputusan pada perusahaan atau organisasi. Oleh sebab itu perlu adanya pemahaman yang mendalam mengenai komponen-komponen dalam sisitem informasi manajemen khususnya brainware agar dapat menghasilkan informasi yang bernilai guna bagi perusahaan atau organisasi agar dapat memperoleh sustainable competitive advantages.

Kata kunci: brainware, informasi, system informasi, manajemen.

\section{A. PENDAHULUAN}

Informasi merupakan salah satu hal yang harus dipenuhi oleh umat manusia, karena informasi merupakan suatu kebutuhan primer. Tanpa informasi internal 
maupun eksternal, sulit bagi para menajer untuk mengambil berbagai keputusan dalam perusahaan. Informasi internal harus disiapkan sendiri oleh berbagai unsur perusahaan, sedangkan informasi eksternal diperoleh baik dari alat-alat komunkasi modern.

\section{PEMBAHASAN}

\section{Konsep Dasar Sistem Infromasi Manajemen}

\section{System informasi manajemen}

System informasi manajemen adalah sebuah system informasi yang selain melakukan pengolahan transaksi yang sangat berguna untuk kepentingan organisasi, juga banyak memberikan dukungan informasi dan pengolahan untuk fungsi manajemen dalam pengambilan keputusan. System informasi manajemen secara umum dapat dilakukan sebagai sebuah system manusia dan mesin terintegrasi dalam menyediakan informasi guna mendukung fungsi operasi manajemen dan penentuan alternative tindakan dalam sebuah organisasi system tersbut.

\section{Tujuan system informasi manajemen}

Tujuan dibentuknya system informasi manajemen adalah supaya organisasi memilki informasi yang bermanfaat dalam pembuatan keputusan manajemen. Manajemen baik yang menyangkut keputusan-keputusan yang strategis sehingga sim adalah suatu sisitem yang menyediakan kepada pengelola organisasi data maupun informasi yang berkaitan dengan pelaksanaan tugas-tugas organisasi. ( Ahmad, 2018).

\section{Manfaat system informasi manajemen}

1. Bisa menghasilkan suatu system yang sangat berguna dalam suatu pendidikan 
2. Menjadikan informasi ysng lebih bermanfaata dalam suatu pendidikan tersebut

3. Mengetahui informasi yang kita butuhkan

4. Lebih mudah mengelola transaksi-transaksi

5. Dapat mengurangi yang tidak kepastian didalam system tersebut

\section{Implementsai system informasi manajemen}

Sistem Informasi dan Manajemen merupakan salah satu komponen yang tidak dapat dipisahkan dari aktivitas pendidikan. Kedua komponen ini memiliki hubungan dalam membentuk karakteristik dunia pendidikan. Manajemen dalam menggambarkan hubungan kedua aspek tersebut, adalah pendidikan sebagai penggeraknya terhadap sistem informasi pendidikan, sedangkan Sistem Informasi Manajemen (SIM) akan menjadi penentu kinerja pendidikan. SIM dapat dijadikan alternatif pilihan untuk meningkatkan kualitas madrasah dalam menyajikan aktivitasnya secara lebih cepat dan memiliki nilai tambah sehingga dunia pendidikan akan menghasilkan output yang memiliki daya jual yang tinggi.

\section{Peranan system informasi manajemen}

Secara umum, peranan system informasi manajemen dalam lembaga pendidikan adalah sebagai berikut:

1. SIM menyediakan informasi bagi para pengelola pendidikan untuk pengambilan keputusan yang bersifat taktis. SIM menyediakan informasi menyangkut informasi strategis yang diperlukan untuk menentukan langkah pendidikan.

2. Teknologi Informasi adalah suatu teknologi yang digunakan untuk mengolah data, termasuk memproses, mendapatkan, menyusun, menyimpan, memanipulasi data dalam berbagai cara untuk menghasilkan informasi yang berkualitas, yaitu informasi yang relevan, akurat dan tepat waktu

3. _Proses manajemen didefinisikan sebagai aktivitas - aktivitas : • Perencanaan Formulasi terinci untuk mencapai suatu tujuan akhir tertentu adalah aktivitas manajemen yang disebut perencanaan. ${ }^{\circ}$ 
4. _Sistem Informasi Akademik $\neg$ Sistem Informasi Akademik secara khusus dirancang untuk memenuhi kebutuhan Sekolah atau Perguruan Tinggi yang menginginkan layanan pendidikan yang terkomputerisasi untuk meningkatkan kinerja, kualitas pelayanan, daya saing dan kualitas SDM yang dihasilkannya.

5. _Sistem Informasi Akademik memberikan kemudahan dalam mengelola : • Data Guru atau Dosen - Data Siswa atau Mahasiswa - Data Mata Pelajaran atau Kuliah - Data Nilai Siswa atau Mahasiswa Sistem Informasi Akademik dikembangkan secara aktif dan kontinu. Setiap pengguna Sistem Informasi Akademik berhak memberikan masukan-masukan positif berdasarkan kebutuhan mereka.

\section{PENUTUP}

\section{Kesimpulan}

Berdasarkan pembahsan diatas system informasi maanajemen sangat lah dibutuhkan dalam suatu lembaga pendidikan karena, system informasi manajemen sangat membantu didalam lembaga pendidikan. Dengan adanya system informasi manajemen ini lembaga pendidikan lebih mudah mengetahui informasi-informasi diluar.

\section{Saran}

Untuk meningkatkan kualitas pendidikan sangat perlu pengelolaan system informasi manajemen ini dengan dengan sebaik mungkin .

\section{DAFTRA PUSTAKA}


Jimmy Chr L. Goal .2008. Sistem Informasi Manajemen. Institute Perbanas . Depres.

Sidh Rahmawati. Peranan Breainware Dalam Sistem Informasi Manajemen. Jurnal Computech dan Bisnis, vol.7, No. Hal 19-29. 